\title{
Hydrograph modeling with rational modified method
}

\author{
Mega Yulisetya Widasmara ${ }^{1, *}$, Pramono Hadi $^{2}$, and Nugroho Christanto ${ }^{2}$ \\ ${ }^{1}$ Planning and Management of Coastal Area and Watershed, Faculty of Geography, Universitas Gadjah Mada, Indonesia \\ ${ }^{2}$ Department of Environmental Geography, Faculty of Geography, Universitas Gadjah Mada, Indonesia
}

\begin{abstract}
Water, a vital natural resource for a human being, could bring negative effects such as flood and landslides. The best way to show the hydrological process is called "model". One of them is Modified Rational Method (MRM). There are several types of MRM base on its equation modification. Hydrological mass balance or kinematic wave in order to route the flow. With this model modification, the output of the model is not only peak discharge but also unit hydrograph. Model modification was done in the calculation of peak discharges by assigning the $\mathrm{C}$ value (coefficient runoff), A value (area) and land characteristic (soil texture, Manning roughness coefficient, and saturation coefficient in the pixel basis. PCRaster software allows us to perform discharge calculation on each pixel. Flow accumulation by using kinematic wave was done to get the unit hydrograph. Three (3) flood events were used to run the model validation, i.e. January 21, January 22, and February 10, 2016. Each event has different rainfall characteristics. The result of this model was DRO hydrograph. Based on the baseflow separation of the observed hydrograph as well as the hydrograph from the model, we found that the flow through the outlet during discharge recession is the base flow. The accuracy value is quite good, i.e. 10-30\%. The result of the model shows a different response between direct runoff and base flow, while time to peak was faster than the recession time.
\end{abstract}

\section{Introduction}

Water is a quite important natural resource for human living and other living forms. The existence of water resources can be used as a means of recreation, traffic, and pollution reduction [1]. Intense rainfall could cause dangerous events such as floods and landslides. This could cause human and infrastructure damage. Lack of water resources as a factor inhibiting agriculture in an area, especially for areas with the main livelihood is agriculture. Agriculture as a small economic sector is susceptible to drought [2]. Indirectly, this condition can affect various sectors such as economy, social, and environment, especially in terms of water availability [3]. The best management measures to address the adverse effects of the hydrological process are the models [4].

Hydrograph flow modeling is an important study to analyze environmental problems. This is related to the management of water resources and disaster mitigation $[5,6]$. In addition, flow hydrographs represent watershed characteristics. There are several approaches developed for discharge calculation. These are empirical and physical approaches. The rational method is one of the empirical approaches that have long been developed since the $1850 \mathrm{~s}$. The method is suitable for a relatively small area, which is less than 81 ha. Limitations of this method are only suitable for use in small areas $[7,8]$. Currently, rational methods are used only to calculate peak discharge. Application of other discharge or runoff models, typically using relatively long periods (continuous and long-term) and time series data requirements. In this research, the method of discharge calculation uses floods event data (event base) rainfallrunoff, which representative data is taken during the Orainy season $[9,10]$. The model is built with DEM (Digital Elevation Model) data, ground saturation coefficient, and land use.

Rational Modified Method (RMM) is the development of rational methods. Development by adding the principle of surface hydrological balance or kinematic wave in order to route flow [11]. Calculation of flow debit on a smaller area, called pixels, so that the spatial resolution of the data used may affect the model results. This method is able to model the flow spatially and dynamically. Dynamic means the process contained in the watershed can be modeled over time. The process can be water movement, sediment, and landscape changes. The advantages of this method can be used to simulate the amount of discharge based on the occurrence of rain in space and time is quite detailed with the data needs are not much. The result of this model is Hydrograph Unit (HU). HU calculations still use manual mathematical calculations, such as a synthetic HU based on the geomorphological feature, Soil Conservation Service (SCS) method, and the Sacramento Soil Moisture Accounting (Sac-SMA) model [12-14]. RMM uses a computer program, PC Raster. This model is applied to small watershed, Bompon watershed, Magelang, Central Java, Indonesia.

* Corresponding author: megayulisetyawidasmara@gmail.com 


\section{Methods}

\subsection{Study area and data}

This research was conducted in Bompon Watershed (279 ha), Magelang, Central Java, Indonesia (see Figure 1). Geologically, the research location is formed from Sumbing deposits and Menoreh Mountains. The material at the site of the study was derived from the alteration process formed during the tertiary period and the thick layer of soil. Annual rainfall ranges from 2,506.26 mm to $4,617.78 \mathrm{~mm}$ with a rainy season from November to February and dry season from July to October. The formed rivers are dominated by intermittent river, while perennial river (river that flows throughout the year) is formed in the downstream. The highly fluctuating hydrological conditions in the Bompon watershed may cause drought during the dry season, so this location is chosen for the application of flow hydrograph modeling using the RMM method.

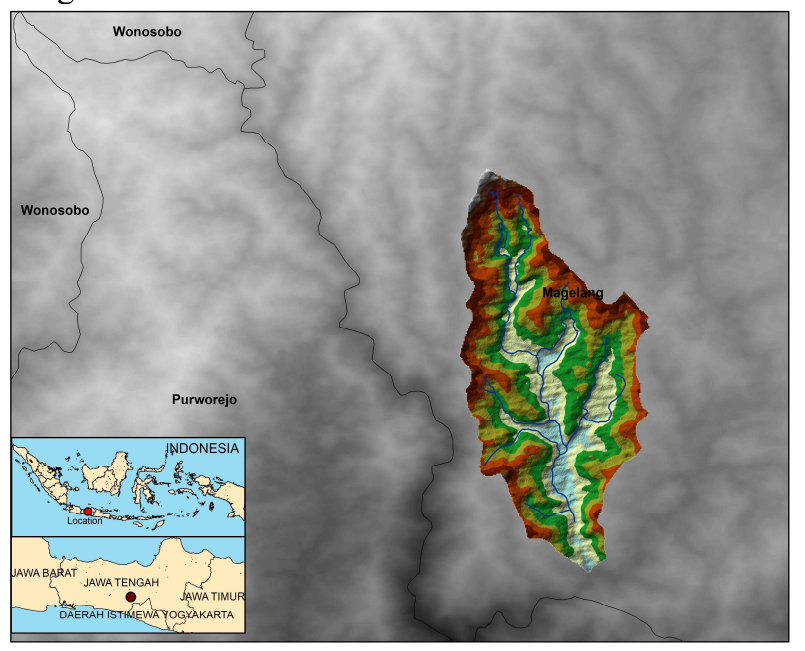

Fig. 1. Study area (Bompon, Watershed)

Measurement of rainfall-runoff data using monitor station mounted on the outlet. Other data are data of watershed characteristics, including soil saturation coefficient data, manning data, and DEM data. The soil saturation coefficient represents the soil characteristics at the site of the study. The data is obtained from laboratory test results with soil sampling based on landform type. Manning data represents the level of surface roughness based on landuse type. DEM data greatly determine the detail quality of model results. The DEM data used in this study comes from TerraSAR radar imagery with a spatial resolution of 9 meters.

\subsection{Model simulations}

PC Raster computer program is used to calculate DRO (Direct Runoff) value and create UH (Unit Hydrograph). Any mathematical calculation from beginning to end is done on the software. The software provides simulation by a white box, so the calculation formula can be determined by itself according to the used method. Land characteristics are represented in manning roughness coefficients $(\mathrm{N})$ and saturation coefficients $(\mathrm{Ks})$. The $\mathrm{N}$ values of Watershed Bompon are described in Table 1.

Table 1. Manning roughness coefficient

\begin{tabular}{|l|c|}
\hline Land use & N \\
\hline Mixed forest land & 0.900 \\
\hline Bare land & 0.600 \\
\hline Built-up land & 0.530 \\
\hline Irrigation agricultural & 0.560 \\
\hline Cropland & 0.545 \\
\hline
\end{tabular}

Saturation Coefficients $(\mathrm{Ks})$ is the ratio between the volume of water and the pores in the soil. The value of Ks Bompon Watershed is described in Table 2.

Table 2. Saturation coefficient of Bompon Watershed

\begin{tabular}{|l|c|}
\hline Unit Landform & Ks \\
\hline Hilltop & 53.13 \\
\hline Upper slope & 56.78 \\
\hline Middle slope & 57.84 \\
\hline Lower slope & 67.06 \\
\hline Foot plain & 80.00 \\
\hline Alluvial plain & 83.32 \\
\hline
\end{tabular}

The calculation of the discharge (Q) value using RMM is the result of modification of the rational method on the parameters of the runoff coefficient and the extent of the area. Calculation of discharge on each pixel, then routing using kinematic wave method. The calculation of the discharge value of each pixel is formulated as follows.

$$
\begin{aligned}
& P=\left(P_{1}+P_{2}+\ldots+P_{n}\right) / \mathrm{n} \\
& \text { Inf }=|P-K s| \\
& Q=(P-\operatorname{Inf}) \times A
\end{aligned}
$$

Here in, $P$ is average rainfall intensity in $\mathrm{mm} / \mathrm{h}, \mathrm{P} 1$, $\mathrm{P} 2, \mathrm{Pn}$ are rainfall intensity in station $1,2, \mathrm{n}$, and $\mathrm{n}$ is total station. Inf is average infiltration in $\mathrm{mm} / \mathrm{h}$. KS is saturation coefficients, $A$ is pixel area's in $\mathrm{mm}^{2}$, and $Q$ is discharge in $\mathrm{mm}^{3} / \mathrm{s}$.

Flow routing of the flow rate value of each pixel uses the LDD (Local Drain Direction) data extracted from the DEM data. Streams will be directed at a single control point that is a watershed outlet. The calculation formulas are adapted to the Raster PC programming language [15]. The flow on a pixel is directed to the channel according to the slope. calculation of flow discharge on channel. The calculation uses the following formula [16]. 


$$
\begin{aligned}
& \alpha=S^{1 / 2} /\left(N \times W^{2 / 3}\right) \\
& Q_{c}=\alpha \times A^{\beta} \\
& q=\left[\left(\partial A_{\mathrm{c}}\right) / \partial t\right]+\beta_{\mathrm{c}} \times P_{\text {pixel }} \times\left[\left(\partial A_{\mathrm{c}}\right) /(\partial x)\right]
\end{aligned}
$$

Here in, $N$ is roughness coefficient, $S$ is slope channel, $W$ is width channel, $\alpha \alpha$ is flow velocity, $\beta$ is kinematic wave coefficient, $A$ is wet cross-section area's. $t$ is duration for one-time step, $x$ is pixel length, $Q_{c}$ is discharged accumulation, and $q$ is discharged in the outlet.

The formula is simplified using the script on pc raster program with the following formula.

$$
Q=\text { kinematic }(L D D, Q c, \mathrm{q}, \alpha, \beta, 1, \partial \mathrm{t}, \partial \mathrm{x})
$$

\section{Results and discussions}

\subsection{Hydrograph simulation with MRM}

The flow hydrograph simulation with MRM is conducted on 3 flood events, i.e., January 21, 2016, January 22, 2016, and February 10, 2016. Flood events on 21 January 2016 are represented in flow hydrograph form (Figure 2). The flow hydrograph explains the relationship between surface flow discharges over time. The peak discharge (Qp) modeling results are 1.049 $\mathrm{m}^{3} / \mathrm{s}$. Time to reach the peak (Tp) for a 5-time step or 75 min. Tp flooding against the peak rainfall tends to be the same. This shows that the time to peak condition (Tp) is relatively fast. The volume of surface flow that occurred from this flood event is $140.123,2 \mathrm{~m}^{3}$ with a $5.01 \mathrm{~cm}$ DRO thickness.

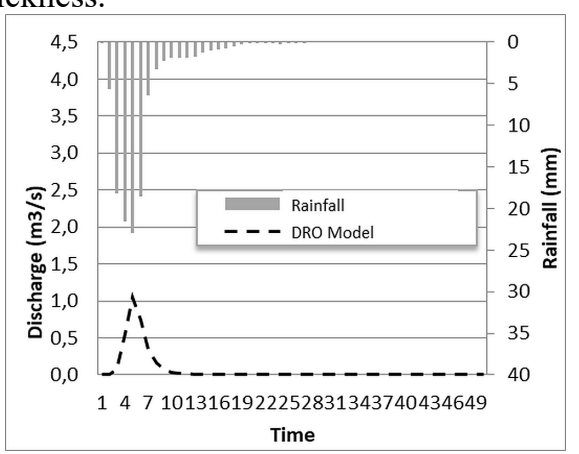

Fig. 2. DRO Hydrograph January 21, 2016

(Analysis Results, 2016)

The flood event on 22 January 2016 is drawn in the form of discharge hydrograph (Figure 3). Qp from the modeling result is $2.68 \mathrm{~m}^{3} / \mathrm{s}$, with time to peak for 6-time step (90 minutes). In accordance with previous flood events, the time to reach the peak of the flood is equal to the peak rainfall. Flood incident on 10 February 2016 is illustrated in the form of discharge hydrograph (Figure 4). The discharge hydrograph on the occurrence of this flood described as floods that occur on two peak rainfalls. Unlike the other rain events. This is one of the drawbacks of this modeling. The second flood event is not counted as a DRO if the flood value is less than the first flood event. The value will be considered as a baseflow. The flood incident on 10 February has a greater rainfall intensity than the intensity of rain in previous flood events. The highest rain intensity at sixth time is $147 \mathrm{~mm} / \mathrm{h}$, with rain thickness of $36.75 \mathrm{~mm}$.

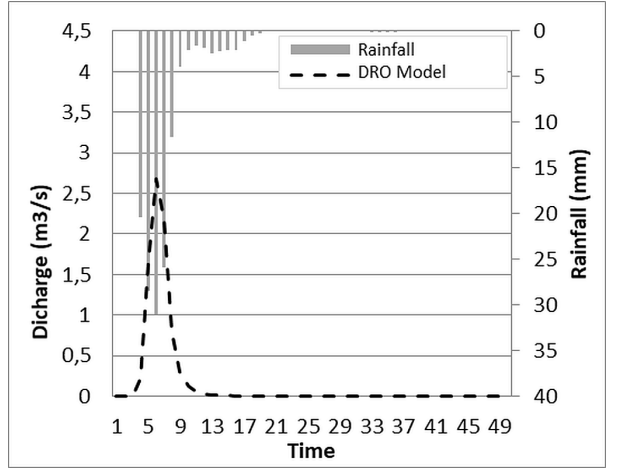

Fig. 3. DRO Hydrograph January 22, 2016

(Analysis Result, 2016)

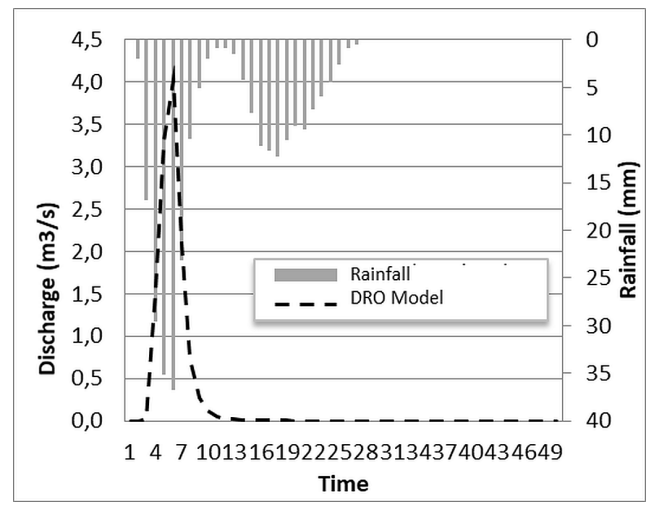

Fig. 4. DRO Hydrographs February 10, 2016

(Analysis Result, 2016)

Discharge debit modeling using MRM method uses assumptions that rainfall is spread evenly across the entire watershed, so that if this method is applied to a relatively large basin, it is necessary to use additional methods that can calculate bulk spatially. Calculation of rainfall value using polygon thiessen method combined with PCA method to determine the value of rainfall in a watershed. However, the value of the rainfall is regional rainfall. Combination of models is needed to calculate the value of rainfall spatially and the time of rainfall delay into a runoff. It is used to improve the accuracy of rainfall-runoff modeling by MRM method on a larger basin. This method has been applied to rainfall-runoff modeling using ANFIS (Adaptive Neuro Fuzzy Inference System) method [17].

\subsection{Baseflow separation}

Separation of baseflow using model data in the form of Hydrograph Unit. The data shows the value of DRO, while the discharge hydrograph based on monitoring results AWLR (Automatic Water Level Recorder). Separation of floods in the three flood events, i.e. flood events January 21, January 22, and 10 February 2016 (See Figure 5, 6, and 7). 


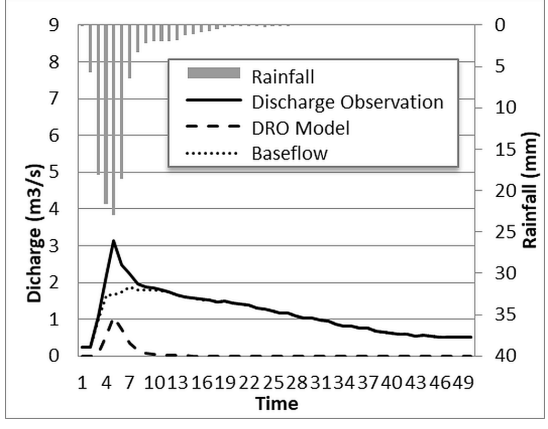

Fig. 5. Baseflow Separation Hydrograph January 21, 2016 (Analysis Result, 2016)

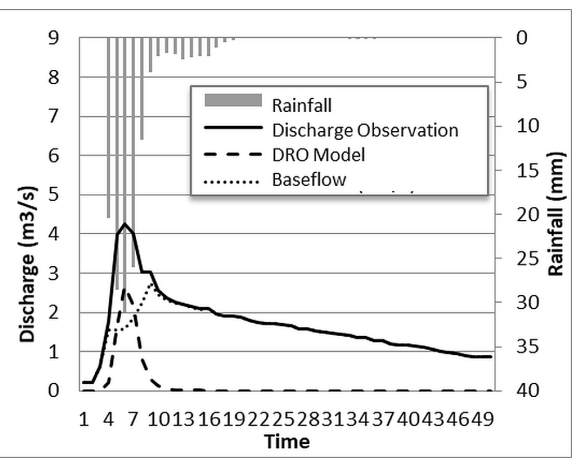

Fig. 6. Baseflow Separation Hydrograph January 22, 2016 (Analysis Result, 2016)

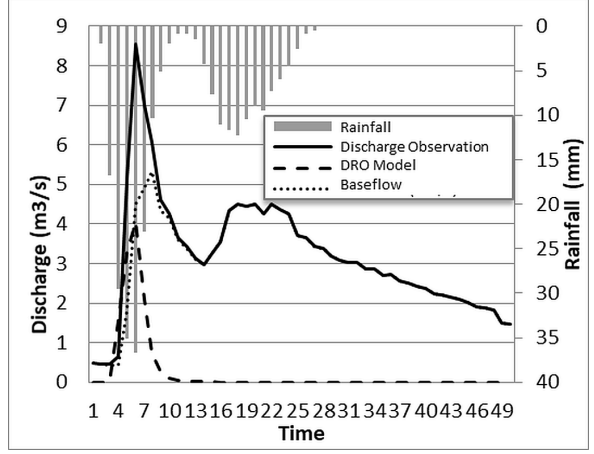

Fig. 7. Baseflow Separation Hydrograph February 10, 2016 (Analysis Result, 2016)

The discharge comes from the baseflow is more dominant than the direct runoff. The flow of river from the runoff is $9.67 \%$ from the flood that occurred in the January $21^{\text {st }}$.

Baseflow is a component of groundwater flow in the river stream. There are many methods used to calculate the baseflow value, but validation is difficult because the baseflow measurements in the field most likely to meet with difficulties, so numerical calculations are developed to estimate the baseflow value [18]. The river flow consists of runoff and baseflow, so in this study, the calculation of baseflow value is exacerbated from the reduction of the runoff value of the modeling results.

\subsection{Calibration and validation}

Calculation of deviation value using method of comparison between modeling result and observation. The parameters compared in this case are the volume and value of the peak discharge (see Table 3 and Table 4).

Table 3. Calculation of deviation values based on DRO Volume

\begin{tabular}{|c|c|c|c|}
\hline \multirow{2}{*}{$\begin{array}{c}\text { Rainfall } \\
\text { event }\end{array}$} & \multicolumn{3}{|c|}{ DRO Volume $\left(\mathrm{m}^{3}\right)$} \\
\hline & Model & Observation & Deviation (\%) \\
\hline Jan-21 & $140,123.20$ & $159,501.38$ & 12.15 \\
\hline Jan-22 & $364,745.97$ & $400,148.32$ & 8.85 \\
\hline Feb-10 & $552,307.60$ & $492,422.51$ & 12.16 \\
\hline
\end{tabular}

Table 4. Calculation of deviation value on peak discharge

\begin{tabular}{|c|c|c|c|}
\hline \multirow{2}{*}{$\begin{array}{c}\text { Rainfall } \\
\text { event }\end{array}$} & \multicolumn{3}{|c|}{ Peak discharge $\left(\mathrm{m}^{3} / \mathrm{s}\right)$} \\
\hline & Model & Observation & Deviation (\%) \\
\hline Jan-21 & 1.05 & 1.48 & 29.11 \\
\hline Jan-22 & 2.68 & 2.68 & 0.00 \\
\hline Feb-10 & 4.04 & 4.04 & 0.00 \\
\hline
\end{tabular}

Performance model measure on the result of flood event modeling using MRM simulation resulted in error value $0-29.11 \%$. The value is in accordance with the desired target, previous research related to rainfall-runoff modeling has an error value of 6-35\% [19]; error $=27$ $\%$ [20]; error $=18-48 \%$ [21].

\section{Conclusion}

The result of discharge modeling using modified rational method is Hydrograph unit or DRO Hydrograph. The discharge that runs through the watershed outlet is dominated by the baseflow. Different responses between direct runoff and baseflow resulting in recession curve of the Bompon watershed tend to be long. Those results also affected by land conditions, with the clay's dominant texture, saturation coefficient, and high roughness level of the land. The accuracy of the model is $10-30 \%$.

Thanks to lectures of Environmental Geography Department, Universitas Gadjah Mada and Transbulent Group Study for their help in giving knowledge and collecting data.

\section{References}

1. Moreno, C. R., Pérez-Sánchez, J., Aparicio, J. S., Asenjo, M. D, The Economic Value of Conjoint Local Management in Water Resources Results from a Contingent Valuation in the Boquerón Aquifer. Science of The Environment, 255-264 (2015)

2. Melkoyan, A, Climate Change Impact on Water Resources and Crop Production in Armenia. Agricultural Water Management , 86-101 (2015) 
3. Khamraev, N, Water Resources and Socio Economic Development in the Stateof the Aral Sea Basin. Hidrological research and Water Management Strategies in Arid and Semi Arid Zone 65-68 (1995)

4. Yesuf, H.M., Assen, M., Alamirew, T., Melesse, A.M., Modeling of sediment yield in Maybar gauged watershed using SWAT, northeast Ethiopia. Catena 127, 191-205 (2015)

5. Arthur, M.R. DeVries, J., Introduction and Application of Kinematic Wave Routing Techniques Using HEC-1 (1993).

6. Wanielista, M. Hidrology and Water Quantity Control. New York: John Wiley and son. (1990)

7. Sivapalan, M., Takeuchi, K., Franks, S.W., Gupta, V.K., Karambiri, H., Lakshim, V., Liang, X., McDonnell, J.J., Mendiondo, E.M., Connell, O., Oki, T., Pomeroy, J.W., Schertzer, D., Uhlenbrook, S., Zehe, E., IAHS decade on Predictions in Ungauged Basins (PUB), 2003-2012: shaping an exciting future for the hydrological sciences. Hydrol. Sci. J. 48, 857880 (2003)

https://doi.org/10.1623/ hysj.48.6.857.51421.

8. Bedient, P.B. Huber, W.C., Hydrology and Floodplain Analysis. Addison-Wesley Publishing Company, 360-364 (1988)

9. Dumairy, Ekonomika Sumberdaya Air Pengantar ke Hidrolika, (1992)

10. Melsen, L.A., Teuling, A.J., Berkum, S.W., Torfs, P.J.J.F., Uijlenhoet, R., Catchments as simple dynamical systems: a case study on methods and data requirements for parameter identification. Water Resour. Res. 50, 5577-5596 (2014) https://doi.org/10.1002/2013WR014720.

11. Correa, A., Windhorst, D., Crespo, P., Célleri, R., Feyen, J., Breuer, L., Continuous versus event-based sampling: how many samples are required for deriving general hydrological understanding on Ecuador's páramo region? Hydrol. Process. 30, 4059-4073 https://doi.org/10.1002/hyp.10975

12. Hua, J., Liang, Z., Yu, Z, A Modified Rasional Formula for Flood Design in Small Basin. Journal pf the American Water Resources Assosiation , 10171025 (2003)

13. Bhunya, P.K. et al., Hybrid model for derivation of synthetic unit hydrograph. J. Hydrol. Eng. 10 (6), 458-467 (2005)

14. Zhang, Z., Koren, V., Reed, S., Smith, M., Zhang, Y., Moreda, F., Cosgrove, B.A., SAC-SMA a priori parameter differences and their impact on distributed hydrologic model simulations, J. Hydrol. 420-421, 216-227 (2012)

15. Singh, P.K., Mishra, S.K., Jain, M.K., 2013. A review of the Synthetic Unit Hydrograph: from the empirical UH to advanced geomorphological methods. Hydrol. Sci. J. 59 (2), 239-261 (2015)

16. Asch, V. Tang, C., Alkema, D., Zhu, J., Zhou, W., An Integrated Model to Assess Critical Rainfall Thresholds for Run-out Distances of Debris Flows, Springer Science, 299-311 (2013)
17. Bartoletti, N., Casagli, F., Marsili-Libelli, S., Nardi, A., Palandri, L., Data-driven rainfall/runoff modelling based on a neuro-fuzzy inference system. Envi Model Soft, 106, 35-47 (2018)

18. Parington, D., Brunner, P., Simmons, C.T., Werner, A.D., Therrien, R., Maier, H.R., Dandy, G.C., Evaluation of outputs from automated baseflow separation methods against simulated baseflow from a physically based, surface water-groundwater flow model. Journal of Hydrology, 458-459, 28-39 (2012)

19. Hailegeorgis, T.T, Alfredsen, K., High spasialtemporal resolution and integrated surface and subsurface precipitation modelling for a small stormwater catchment, J. Hydrol, 557, 613-630 (2018) https://doi.org/10/1016/j.jhydrol.2017.12.054

20. Coutu, S., Giudice, D.D., Rossi, L., Barry, D.A., Parsimonious hydrological modelling of urban sewer and river catchments. J. Hydrol. 464-465, 477-484 (2012)

21. Gironas, J., Niemann, J.D., Roesner, L.A., Rodriguez, F., Andrieu, H., A morphoclimatic instantaneous unit hydrograph model for urban catchment based on the kinematic wave approximation. J. Hydrol. 377 (3-4), 317-334 (2009) 